\title{
Adult Immunoblastic Lymphoma
}

National Cancer Institute

\section{Source}

National Cancer Institute. Adult Immunoblastic Lymphoma. NCI Thesaurus. Code C7873.

A morphologic variant of diffuse large B-cell lymphoma occurring in adults. It is

characterized by the presence of large lymphoid cells with abundant cytoplasm and prominent nucleoli. 